\title{
Implementasi dan Edukasi Sistem Keamanan Elektronik di Rumah Ibadah Dukuh Pingit dan Gunturan Karanganyar
}

\section{Faisal Rahutomo*1, Sutrisno², Subuh Pramono ${ }^{3}$, Meiyanto Eko Sulistyo", Muhammad Hamka Ibrahim ${ }^{5}$, Febri Liantoni' 6}

\author{
1,2,3,4,5Teknik Elektro, Universitas Sebelas Maret, Indonesia \\ ${ }^{6}$ Pendidikan Teknologi Informatika dan Komputer, Universitas Sebelas Maret, Indonesia \\ *e-mail: faisal_r@staff.uns.ac.id ${ }^{1}$, sutrisno@staff.uns.ac.id ${ }^{2}$, subuhpramono@staff.uns.ac.id ${ }^{3}$, \\ mekosulistyo@staff.uns.ac.id ${ }^{4}, \underline{\text { hamka@staff.uns.ac.id }}^{5}, \underline{\text { febri.liantoni@staff.uns.ac.id }}^{6}$
}

\begin{abstract}
Abstrak
Situasi sosial dan keamanan masyarakat masa kini terkadang muncul masalah terkait keyakinan agama. Berita-berita tentang penyerangan terhadap imam di masjid, pencurian kotak amal, pencurian alat pengeras suara, upaya pembakaran, vandalisme, hingga terorisme muncul. Pengamanan rumah ibadah secara ketat selama 24 jam memerlukan petugas keamanan yang menyedot anggaran rumah ibadah. Seringkali pengurusan rumah ibadah dilakukan secara sukarela sehingga tidak bisa dikontrol 24 jam terusmenerus oleh petugas masjid. Di sisi lainnya teknologi pengamanan secara elektronik telah tersedia dan dimanfaatkan secara luas di masyarakat. Untuk mengatasi celah yang ada ini, rumah ibadah di masa sekarang perlu memanfaatkan sistem keamanan elektronik. Untuk itu di dalam usulan ini diajukan judul implementasi dan edukasi sistem keamanan elektronik di rumah ibadah. Penyediaan perangkat dan pelatihan operasional diberikan pada beberapa rumah ibadah mitra. Berdasarkan pengukuran umpan balik kuesioner, hasilnya dirasakan positif oleh masyarakat. Dengan demikian aktivitas yang tidak selayaknya dilakukan dapat dipersempit ruang geraknya.
\end{abstract}

Kata kunci: Keamanan Elektronik, Rumah Ibadah

\begin{abstract}
In today's social and community situation, security problems often arise and graze religious beliefs. News of attacks on imams at mosques, theft of charity boxes, theft of loudspeakers, attempted arson, vandalism, and terrorism emerged. Strict security of worship places requires security officers who are needed to be paid. Often, the houses of worship management are done voluntarily, so it does not be controlled 24 hours continuously. On the other hand, electronic security technology has been widely available and used in society. To overcome this gap, houses of worship nowadays need to be supported by an electronic security system. For this reason, this paper proposes the implementation and education of electronic security systems in places of worship. Provision of equipment and operational training is provided to several houses of worship partner. Thus the security and honor of the house of worship can be better maintained. Therefore, supporting the achievement of a safe, peaceful, and prosperous society.
\end{abstract}

Keywords: Electronic Security Device, Worshiping Place

\section{PENDAHULUAN}

Mitra pada pengabdian kepada masyarakat ini adalah rumah ibadah masjid yang terletak di Kabupaten Karanganyar, Kecamatan Karanganyar, Kelurahan Bolong. Dua masjid yang menjadi objek pengabdian ini adalah Masjid jami' Pingit dan Masjid Baiturahman Gunturan. Masing-masing masjid berkapasitas sekitar 300 orang dengan fasilitas standar berupa tempat ibadah, tempat bersuci, tempat parkir, dan kamar kecil. Kedua rumah ibadah ini aktif menjalankan ibadah 5 waktu, dan juga ibadah satu mingguan di hari Jumat. Pendidikan anakanak diwadahi oleh kegiatan Taman Pendidikan Quran (TPQ). Peta lokasi mitra ada di Gambar 1. Sedangkan penampakan luar dan interior rumah ibadah berturut-turut ada di Gambar 2 dan 3.

Kedua rumah ibadah terletak di desa pertanian padi. Selain bertani, penduduk usia muda banyak yang pergi merantau ke luar daerah ataupun bekerja di pabrik. Kondisi tersebut mengakibatkan lingkungan yang cenderung sepi, tenang, dan lengang. Masyarakat cenderung saling percaya, tidak terlalu memperdulikan faktor keamanan secara ketat. Kondisi semacam 
parkir motor dengan kunci tetap menempel di kendaraan, atau pintu yang dibiarkan terbuka sering ditemui.

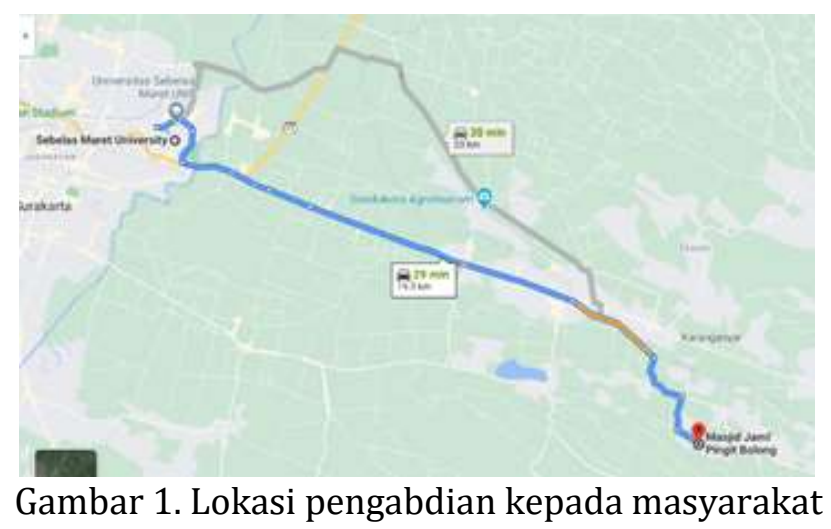

Sayangnya kondisi masyarakat semacam itu ternyata dimanfaatkan oleh beberapa pihak yang kurang bertanggung jawab. Pelaku tidak diketahui apakah penduduk lokal atau pendatang. Beberapa kejadian yang pernah terjadi antara lain: pencurian kotak amal, pencurian microphone, pencurian alas kaki, dan pencurian perangkat pengeras suara. Selain kejadian lokal yang pernah terjadi tersebut, di sisi eksternal juga banyak berita terkait kejahatan yang mengarah ke SARA yang terjadi di masyarakat di rumah ibadah. Media massa beberapa kali melaporkan adanya penyerangan di masjid (Aji YK Putra, 2020; Fitrazana, 2018), pelemparan molotov (Achmad, 2020), perilaku mesum (Faisol, 2019), kejadian pemboman (Riza Wahyu Pratama, 2019), pencurian kotak amal (Yakub Mulyono, 2021), hingga terorisme.

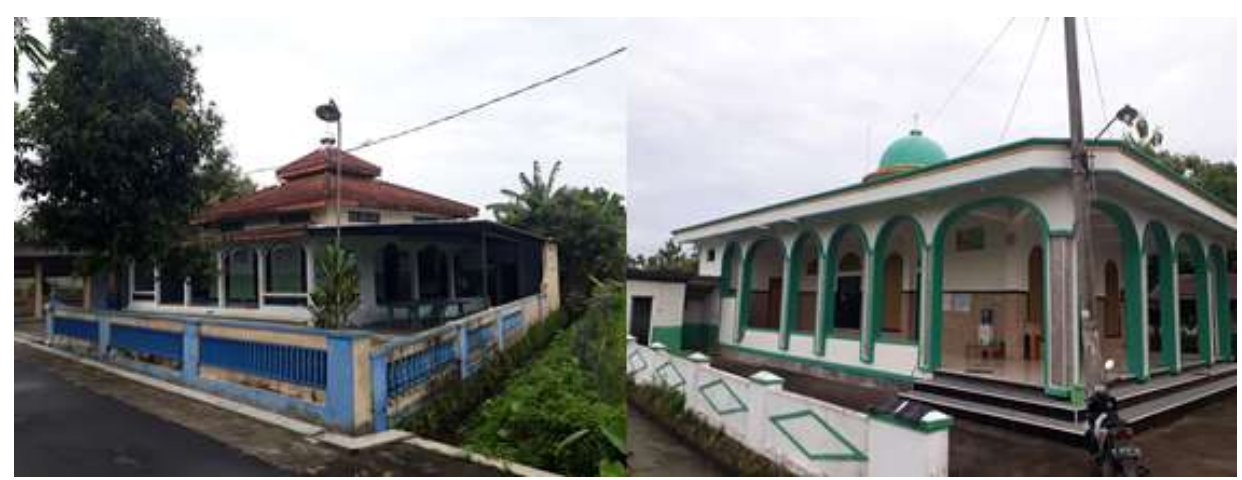

Gambar 2. Masjid Pingit dan Gunturan

Sebenarnya, teknologi yang mendukung untuk monitoring and surveillance telah tersedia dengan lengkap (Adelina Ibrahim, 2020; Heba A. Kurdi, 2014; U.S. Department of Homeland Security, 2013). Di sisi lainnya dari segi ekonomi, nilai barang-barang dimaksud masih dapat dijangkau masyarakat. Hanya saja dari segi operasional teknologi baik dari proses instalasi, operasional, dan perawatan belum dikuasai dengan baik secara mandiri. Ketergantungan kepada pihak vendor dapat mengakibatkan pengeluaran yang tidak bisa diperkirakan, sehingga menyebabkan masyarakat desa masih enggan memanfaatkannya.

Berdasarkan paparan tersebut di atas, pengabdian kepada masyarakat ini melakukan implementasi dan edukasi sistem keamanan elektronik. Harapan dari pengabdian ini, masyarakat menjadi lebih memahami teknologi ini. Selain dari segi operasional dan perawatannya, kalangan pemuda dapat diberi pemahaman sehingga memungkinkan untuk kedepan merintis usaha instalasi sistem pengamanan elektronik ini di tempat-tempat lainnya. 


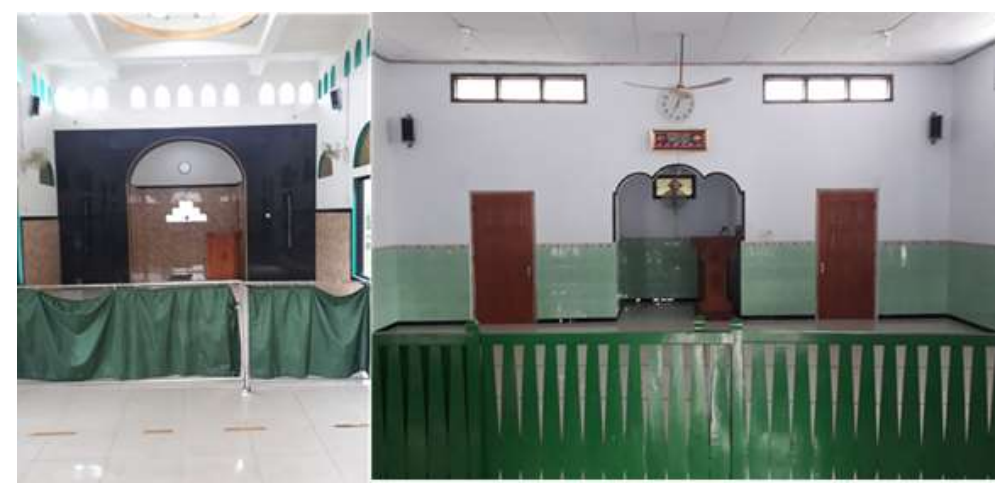

Gambar 3. Interior Masjid Gunturan dan Pingit

\section{METODE}

Solusi yang ditawarkan terdiri atas beberapa tahap. Pertama solusi instan yang ditawarkan berupa instalasi sistem keamanan elektronik secara langsung di rumah ibadah yang menjadi mitra. Selanjutnya pengurus masjid diberikan pelatihan cara operasional sistem dan juga perawatannya. Tahapan ketiga telah menjurus ke arah pendampingan rintisan usaha oleh para pemuda dengan pelatihan teknik instalasi dan perawatan perangkat-perangkat dimaksud. Harapannya para pemuda tersebut dapat memiliki pengetahuan cukup secara teknis untuk melakukan instalasi dan perawatan di tempat-tempat lainnya, yang bisa mereka jadikan rintisan usaha mereka sendiri.

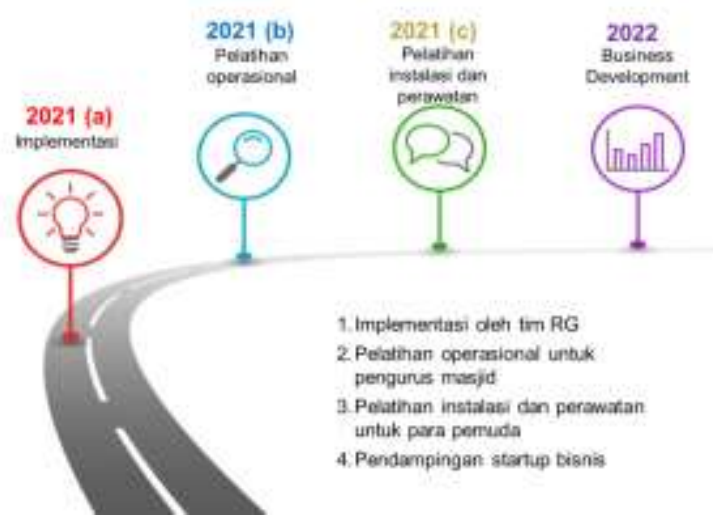

Gambar 4. Peta jalan pengabdian kepada masyarakat

Implementasi yang dimaksudkan disini sebagai berikut. Sistem keamanan elektronik di rumah ibadah tersusun dari beberapa kamera pengawas yang terhubung ke kotak penyimpanan. Terdapat 4 titik yang ditargetkan untuk instalasi, 2 titik eksternal dan 2 titik internal. Titik-titik yang dipilih diusahakan mampu menjangkau sudut pandang yang tepat untuk mengawasi keadaan di seluruh rumah ibadah. Dengan demikian diperlukan instalasi listrik juga yang mendukung untuk kamera yang dipasang. Antara kamera pengawas dengan kotak penyimpanan terhubung dengan kabel video. Di dalam kotak penyimpanan juga terdapat media penyimpanan tetap berupa harddisk. Pantauan kamera pengawas yang ada sebenarnya dapat pula diikuti melalui sebuah layer monitor. Akan tetapi untuk instalasi di lingkungan pedesaan monitor ini belum diperlukan.

Solusi dan luaran yang dituju pada pengabdian ini sebagai berikut. Implementasi sistem dilaksanakan oleh tim RG dengan dukungan para mahasiswa. Tim mengidentifikasi titik-titik lokasi yang diperlukan di lokasi. Titik dimaksud berupa titik kamera eksternal, titik kamera internal, titik posisi kotak perekam, dan titik sumber daya. Setelah peralatan terpasang di posisi masing-masing, kemudian dilakukan pengukuran titik-titik kamera ke lokasi kotak penyimpanan. Ukuran yang diperoleh digunakan untuk belanja kabel penghubung. Kabel yang 
telah dibeli kemudian dipasang dengan pengaman duck atau cable clip hingga terpasang rapi. Setelah semua instalasi fisik terpasang, sistem diuji operasionalnya, diunduh hasilnya pada waktu terkait. Pada tahapan ini pengabdian masyarakat telah memberikan sumberdaya untuk masyarakat secara langsung. Mahasiswa yang terlibat juga dapat direkognisi ke dalam program kampus merdeka. Proses instalasi hingga sistem berjalan didokumentasikan dengan baik untuk menghasilkan luaran yang dimaksud.

Agar masyarakat lebih berdaya, hibah teknologi terkait didampingi dengan solusi kedua berupa pelatihan operasional. Pengurus masjid dilatih cara penggunaan perangkat ini. Beberapa simulasi kejadian dilakukan untuk melatih pengurus mampu memperoleh barang bukti untuk pelaporan ke pihak kepolisian. Misal simulasi pencurian sound system. Waktu kejadian yang diperkirakan ditentukan untuk kemudian mengunduh rekaman pada rentang waktu dimaksud. Rekaman diekstrak hingga tampak siapa pelaku sebenarnya dari kejadian itu. Apabila pelakunya dikenal dapat dilakukan pendekatan kultural masyarakat untuk mencari solusinya. Apabila pelakunya tidak dikenal masyarakat, bisa dijadikan alat bukti pelaporan ke pihak berwenang. Pelatihan dibuat mengalir dengan pendekatan learning by doing menggunakan bahasa yang dipahami masyarakat. Pelatihan ini didokumentasikan dengan baik untuk menghasilkan luaran yang dimaksud. Luaran yang dituju untuk solusi yang pertama dan kedua adalah publikasi di media massa dan publikasi video dokumentasi kegiatan.

Solusi selanjutnya untuk lebih memberdayakan masyarakat dilakukan dengan cara pencangkokan. Ketika tim RG melakukan instalasi dan pelatihan, kelompok pemuda ikut di dalam proses itu untuk mengamati, mempelajari, dan mencoba hingga menguasai proses instalasi perangkat dimaksud. Menguasai pula cara operasional. Dan diberi wawasan mengenai trouble shooting dan perawatan. Pemahaman yang ada diharapkan dapat dimanfaatkan para pemuda untuk memicu rintisan usaha mereka sendiri, untuk dipasarkan ke kalangan masyarakat secara lebih luas.

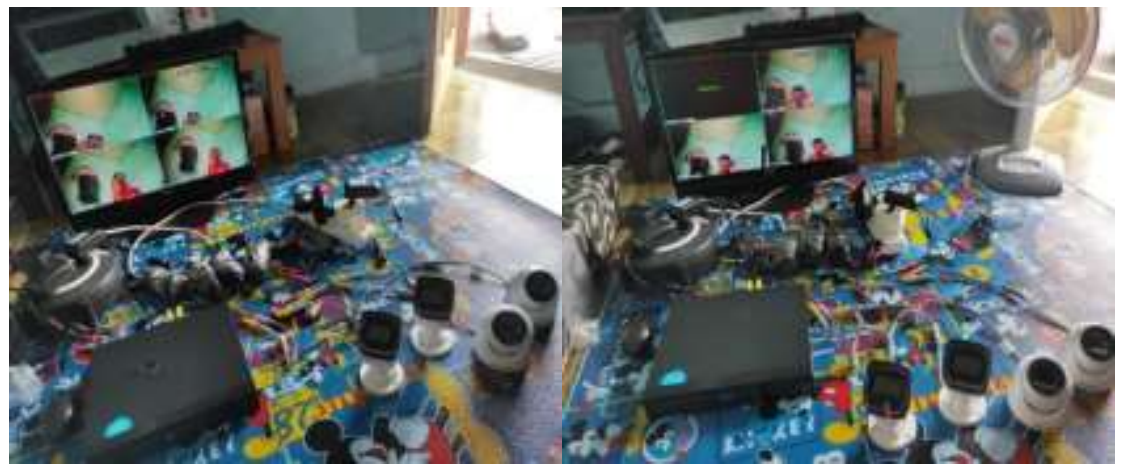

Gambar 5. Pengujian peralatan

\section{HASIL DAN PEMBAHASAN}

Berikut ini pemaparan setiap tahap pengabdian kepada masyarakat, implementasi sistem keamanan elektronik pada rumah ibadah.

\subsection{Pembelian Alat dan Pengujian Fungsi}

Langkah pertama setelah cairnya 70\% anggaran pengabdian adalah mencari perangkat yang tepat sesuai dengan kebutuhan yang ditentukan. Pembelian menggunakan jasa layanan toko daring. Setelah dipesan dan dibeli, alat diuji fungsinya. Hasil pengujian menunjukkan seluruh kamera berfungsi, media penyimpanan juga berfungsi, tetapi satu buah adaptor catu daya rusak. Sebelum alat diserahkan, perlu diganti dengan perangkat yang lainnya terlebih dahulu. Gambar 5 menunjukkan proses pengujian tersebut. 


\subsection{Penyusunan Panduan}

Setelah pengujian selesai, dilakukan proses penyusunan panduan. Panduan ini penting untuk dapat digunakan sebagai referensi instalasi dan perawatan secara mandiri. Panduan yang ada dua, yaitu panduan instalasi dan panduan penggunaan. Tangkapan layar beberapa halaman panduan yang telah disusun tampak pada Gambar 6.

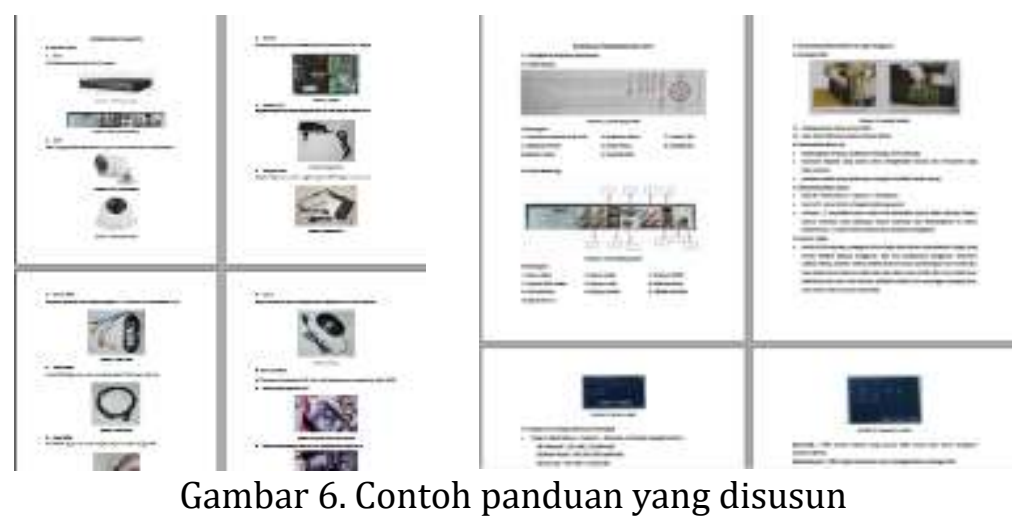

\subsection{Pelatihan, Penyerahan, dan Instalasi}

Selanjutnya adalah pelatihan. Pelatihan dilakukan terhadap 8 orang perwakilan, masingmasing rumah ibadah 4 orang. Perwakilan tiap masjid terdiri atas 2 orang pengurus takmir dan 2 orang pemuda masjid. Pelatihan yang dilakukan berupa pelatihan instalasi dan penggunaan. Kemudian peralatan diserahterimakan kepada perwakilan takmir untuk kemudian diinstalasi bersama-sama dengan pemuda masjid yang ada. Pelatihan instalasi, penggunaan, dan serahterima alat berturut-turut ditunjukkan oleh Gambar 7, 8, dan 9. Pada proses ini, pengurus masjid dipandu oleh beberapa mahasiswa T. Elektro UNS sebagai tenaga pendukung pengabdian.

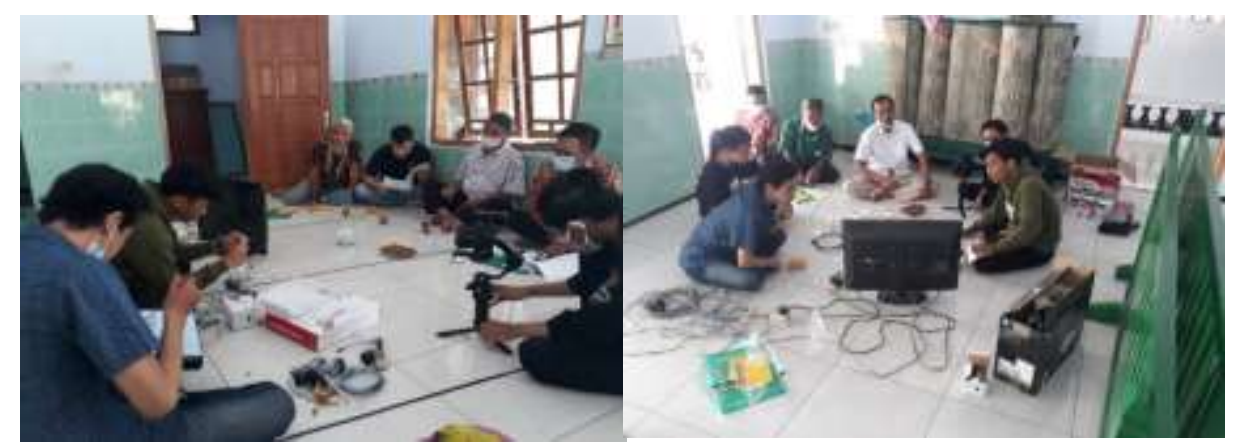

Gambar 7. Pelatihan instalasi

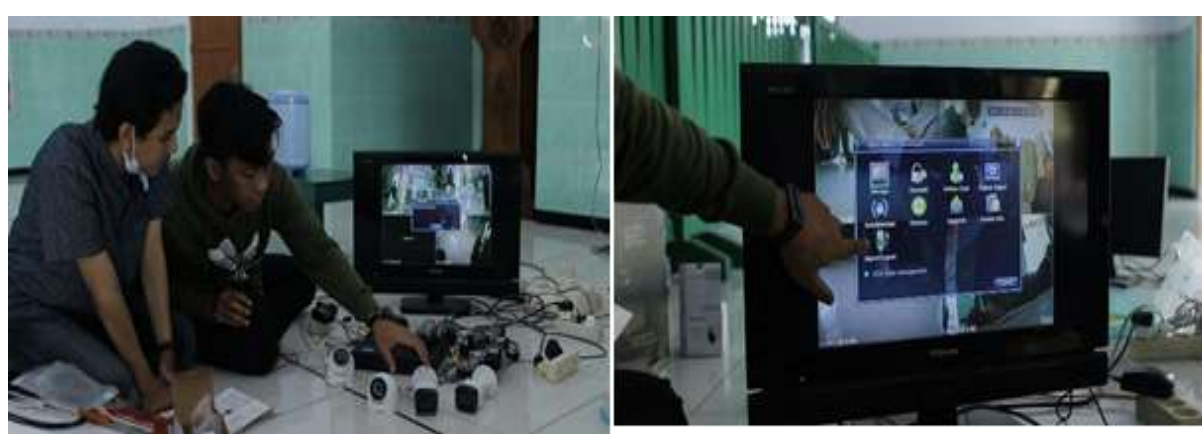

Gambar 8. Pelatihan fitur perekaman 


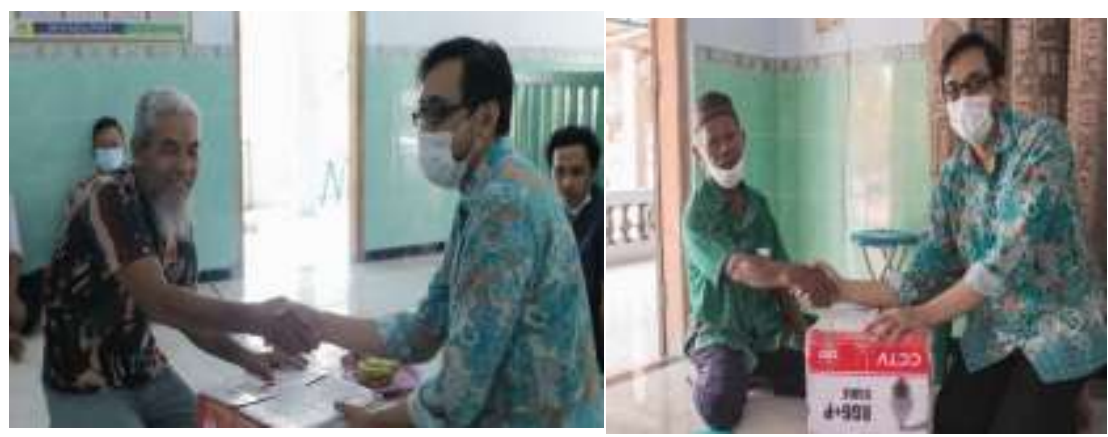

Gambar 9. Serah terima alat

\subsection{Evaluasi}

Evaluasi Pelatihan dilakukan dengan membagikan kuesioner kepada peserta pelatihan. Peserta diminta untuk memberikan responnya pada setiap pertanyaan yang terdiri dari 2 kategori. Pertanyaan yang pertama tentang materi pelatihan, yang kedua tentang pemateri. Para peserta tersebut diminta untuk memilih jawaban disetiap pertanyaan dari rentang skala 1 sampai 5. Perhitungan evaluasi pelatihan dengan rincian hasil tampak pada Tabel 1.

Tabel 1. Evaluasi

\begin{tabular}{lclc}
\hline Pertanyaan & \% & Pertanyaan & \% \\
\hline Materi & & Pemateri & \\
Tema & 87 & Penguasaan & 85 \\
Suasana & 85 & Teknik & 80 \\
Kelengkapan materi & 90 & Komunikasi & 82.5 \\
Kelengkapan alat & 90 & & \\
Kemanfaatan & 90 & & \\
\hline
\end{tabular}

Tabel 2. Peta kondisi

\begin{tabular}{|c|c|c|c|c|}
\hline No & Solusi & Subjek & Sebelum & Sesudah \\
\hline \multirow[t]{3}{*}{1} & $\begin{array}{l}\text { Implementasi } \\
\text { sistem }\end{array}$ & Tim RG & $\begin{array}{l}\text { Belum } \\
\text { mengimplementasikan } \\
\text { sistem ke masyarakat }\end{array}$ & $\begin{array}{l}\text { Berhasil } \\
\text { mengimplementasikan } \\
\text { sistem ke masyarakat }\end{array}$ \\
\hline & & $\begin{array}{l}\text { Pengurus } \\
\text { masjid }\end{array}$ & $\begin{array}{l}\text { Belum memiliki sistem } \\
\text { pemantauan } \\
\text { keamanan elektronik }\end{array}$ & $\begin{array}{l}\text { Memiliki sistem } \\
\text { pemantauan } \\
\text { keamanan elektronik }\end{array}$ \\
\hline & & Pemuda & $\begin{array}{l}\text { Belum mengetahui } \\
\text { cara instalasi sistem } \\
\text { semacam ini }\end{array}$ & $\begin{array}{l}\text { Memiliki pengetahuan } \\
\text { cara instalasi }\end{array}$ \\
\hline \multirow[t]{2}{*}{2} & $\begin{array}{l}\text { Pelatihan } \\
\text { operasional }\end{array}$ & $\begin{array}{l}\text { Pengurus } \\
\text { masjid }\end{array}$ & $\begin{array}{l}\text { Belum mengetahui } \\
\text { cara operasional } \\
\text { sistem }\end{array}$ & $\begin{array}{l}\text { Mengetahui cara } \\
\text { operasional sistem }\end{array}$ \\
\hline & & Pemuda & $\begin{array}{l}\text { Belum mengetahui } \\
\text { cara operasional } \\
\text { sistem }\end{array}$ & $\begin{array}{l}\text { Mengetahui cara } \\
\text { operasional sistem }\end{array}$ \\
\hline 3 & $\begin{array}{l}\text { Pelatihan } \\
\text { instalasi dan } \\
\text { perawatan }\end{array}$ & Pemuda & $\begin{array}{l}\text { Belum mengetahui } \\
\text { cara perawatan sistem }\end{array}$ & $\begin{array}{l}\text { Mengetahui cara } \\
\text { perawatan sistem }\end{array}$ \\
\hline
\end{tabular}

Peta kondisi hasil dijabarkan ke dalam Tabel 2. Nampak di dalamnya kondisi subjeksubjek di dalam pengabdian kepada masyarakat ini, baik sebelum maupun setelahnya. Dengan pemetaan kondisi atau kompetensi capaian yang dituju ini, pengabdian masyarakat yang diusulkan diharapkan mencapai sasaran dan bermanfaat guna langsung kepada masyarakat mitra yang dimaksud. Sebagaimana yang telah dibahas di bagian solusi, masalah nyata yang 
dihadapi masyarakat sebenarnya telah mampu diatasi pada 2 solusi awal. Bilamana sebelumnya masyarakat mengalami masalah tindakan kejahatan di rumah ibadah dan belum berdaya menghadapinya, menjadi lebih berdaya. Masyarakat di tahapan awal telah memiliki sistem yang berjalan untuk memantau keamanan yang ada secara elektronik selama 24 jam terus-menerus. Sumberdaya yang diperlukan hanyalah listrik, tidak memerlukan tenaga kerja manusia yang bisa jadi harganya tinggi. Apabila ada tindak kejahatan, masyarakat bisa mereviu siapa pelakunya, hingga memiliki alat bukti yang memadai untuk itu. Bilamana pelaku tidak dikenal orangnya, peralatan yang ada dapat menjadi alat bukti di depan aparat hukum, sehingga bisa ditindaklanjuti oleh pihak-pihak yang berwenang. Solusi ketiga lebih bersifat langkah antisipatif terhadap potensi rintisan usaha yang dapat dilaksanakan para pemuda. Secara pemantauan umum penggunaan alat pengaman elektronik semacam ini belum banyak digunakan masyarakat pedesaan, terutama di rumah ibadah. Padahal potensi ancaman keamanan juga terbukti ada. Langkah-langkah lainnya lebih berupa pemenuhan syarat administratif tim pengabdian ke LPPM. Luaran-luaran yang ditargetkan diupayakan untuk tercapai, baik itu berupa publikasi media massa, publikasi video, dan juga publikasi ilmiah di media ilmiah ber-ISSN (LPPM UNS Surakarta, 2020).

\section{KESIMPULAN}

Evaluasi yang dilakukan tim menunjukkan pengabdian kepada masyarakat ini memiliki manfaat bagi mitra yang dituju. Terdapat beberapa manfaat berlapis yang diterima, baik dari objek maupun subjeknya. Objek yang berlapis selain menyasar bangunan fisik, juga orang yang mengoperasikan dari segmen senior (takmir) dan pemudanya. Lapisan manfaat dari sisi subjek adalah peralatan, pengetahuan instalasi, dan pengetahuan operasional. Respon yang diterima tim pengabdian dari mitra sangat positif. Tampak dari umpan balik yang diterima, tiap soal memiliki nilai tinggi dengan nilai terendah $80 \%$ dan tertinggi $90 \%$. Saran lanjutan bagi pengabdian kepada masyarakat ini adalah perlu dilanjutkan pada pelatihan dan pendampingan perawatan. Harapannya pengabdian ini dapat bermanfaat dalam jangka panjang, tidak hanya sesaat.

\section{UCAPAN TERIMA KASIH}

Ucapan terimakasih kepada Lembaga Penelitian dan Pengabdian kepada Masyarakat Universitas Sebelas Maret Surakarta atas hibah pengabdian kepada masyarakat tahun anggaran 2021 dengan nomor kontrak: 261/UN27.22/HK.07.00/2021.

\section{DAFTAR PUSTAKA}

Achmad, N. M. (2020, December 27). Kronologi Pelemparan Bom Molotov di Masjid Kawasan Cengkareng Versi Warga. Https://Megapolitan.Kompas.Com/Read/2020/12/27/17503061/Kronologi-PelemparanBom-Molotov-Di-Masjid-Kawasan-Cengkareng-Versi-Warga?Page=all.

Adelina Ibrahim, A. A. S. D. A. (2020). KEAMANAN UNTUK PENERAPAN LAYANAN PUBLIK PADA SISTEM PEMERINTAHAN BERBASIS ELEKTRONIK (SPBE): SEBUAH KAJIAN PUSTAKA SISTEMATIS. IJIS - Indonesian Journal On Information System, 5(2). https://doi.org/10.36549/ijis.v5i2.105

Aji YK Putra. (2020, September 16). Kasus Imam Masjid Dibacok Saat Pimpin Shalat di OKI, Polda $\begin{array}{lllll}\text { Sumsel Pastikan } & \text { Tak } & \text { Unsur }\end{array}$ Https://Regional.Kompas.Com/Read/2020/09/16/15324141/Kasus-Imam-MasjidDibacok-Saat-Pimpin-Shalat-Di-Oki-Polda-Sumsel-Pastikan?Page=all. 
Faisol, A. (2019, December 20). Terekam CCTV Berbuat Mesum di Masjid, 2 Remaja Ditangkap Polisi. Https://Regional.Kompas.Com/Read/2019/12/20/17043541/Terekam-CctvBerbuat-Mesum-Di-Masjid-2-Remaja-Ditangkap-Polisi?Page=all.

Fitrazana, F. A. (2018, January 28). Selepas Salat Subuh Berjamaah, Seorang Kiai Dipukuli Hingga Berdarah-darah. Begini Kronologinya. Https://Jogja.Tribunnews.Com/2018/01/28/Selepas-Salat-Subuh-Berjamaah-SeorangKiai-Dipukuli-Hingga-Berdarah-Darah-Begini-Kronologinya.

Heba A. Kurdi. (2014). Review of Closed Circuit Television (CCTV) Techniques for Vehicles Traffic Management. International Journal of Computer Science \& Information Technology (IJCSIT), 6(2), 199-206.

LPPM UNS Surakarta. (2020). Panduan Penelitian dan Pengabdian Kepada Masyarakat. LPPM UNS.

Riza Wahyu Pratama. (2019, April 13). Dalam Sejarah, Masjid Istiqlal Pernah Dua Kali Dibom.

U.S. Department of Homeland Security, S. and T. D. (2013). CCTV Technology Handbook.

Yakub Mulyono. (2021, January 25). Pengakuan Maling Kotak Amal Masjid di Jember Ini Bikin Ngelus Dada. Https://News.Detik.Com/Berita-Jawa-Timur/d-5347897/Pengakuan-MalingKotak-Amal-Masjid-Di-Jember-Ini-Bikin-Ngelus-Dada. 